\section{A TAXONOMIC RE-ASSESSMENT OF THE CENTIPEDE SCOLOPENDRA GIGANTEA LINNAEUS (CHILOPODA: SCOLOPENDRIDAE) AND CONFIRMATION OF ITS OCCURRENCE IN INDIA}

\author{
Vinod Khanna ${ }^{1}$ and B.E. Yadav ${ }^{2}$
}

${ }^{1}$ Zoological Survey of India, Northern Regional Station, 218, Kaulagarh Road, Dehra Dun, Uttaranchal 248195, India

${ }^{2}$ Western Regional Station, Zoological Survey of India, Vidyanagar, Pune, Maharashtra, India

Yadav (1997) recorded the Giant Centipede Scolopendra gigantea Linnaeus based on the study of a single specimen about $20 \mathrm{~cm}$ long, and black in colour, collected from Alibagh, in Raigad district of Maharashtra. Since the species, is known to occur in nearctic and neotropical regions only, especially in Columbia and coastal islands of Venezuella, Khanna (1998) did not agree to the report of transoceanic occurrence of $S$. gigantea Linnaeus, in India. Khanna (2001) did not include the species in his checklist of the Indian species of Scolopendrid centipedes assuming that Yadav (1997) had probably been misled by the size of the species from India.

Recently in the month of Dec 2004, the specimen of S. gigantea, displayed in the Museum of Western Regional Station, Zoological Survey of India, Pune, was re-examined by the senior author, and after being convinced, hereby rectify the error of excluding S. gigantea from the Indian checklist. With this, the total number of known species of scolopendrid centipedes is now raised to 102 . The species is the largest centipede now known from India.

\section{Brief Description}

S. gigantea Linnaeus 1758. Syst. Nat. $10^{\text {th }}$ Ed. 638.

Type Locality: Neotype: US Virgin Island; St. Thomas (Shelley \& Kiser, 2000)

Material Examined: 1.xii.1973, Alibagh, Raigad District, Maharashtra, India, coll. G.M. Yazdani.

Attems (1930) records the body length up to $265 \mathrm{~mm}$ but Shelley and Kiser (2000) documented a specimen of Scolopendra gigantea from Venezuela that is nearly $275 \mathrm{~mm}$ (11in.) long. There are undocumented reports on the web of specimens of around 400mm (16in.) on Curacao.

Head dark olive brown to dark red-brown; cephalic plate with complete longitudinal sutures; prosternum with transverse groove; legs olive green with yellowish ends; II tarsus completely yellow. Cephalic plate densely punctate with two fine longitudinal furrows. Antennae 17 segmented with 7-9 basal segments glabrous. Dental plate more densely punctate than the base, with very small rounded groove in front, and also with a seta; $4+4$ teeth on the dental plate, the inner two

(c) Zoo Outreach Organisation; www.zoosprint.org Manuscript 1317; Received 18 January 2005; Finally accepted 02 August 2005, Date of publication 21 August 2005 being more or less coalesced. First tergal segment with a procurved transverse groove, $2^{\text {nd }}$ tergite with very fine, small and 3-20 with complete paramedian longitudinal furrows. Tergal segment 4-18, with an additional median furrow. Emargination of tergites begins from $4^{\text {th }}$ or $5^{\text {th }}$ segment. Sternite densely punctate with two paramedian longitudinal furrows, deeper in the middle segments but weaker or almost absent in the anterior or posterior segments. End tergite longer than wide (4:3), strongly narrowing behind. First pair of legs with 2, 2-19 with one and $20^{\text {th }}$ without or with tarsal spur. Process of coxopleural considerably long, at the end with 4-9 spines. Prefemur of the anal legs ventro-laterally with 2-3 rows of 2-4 thorns, medially and dorsomedially with 12-15 thorns. Prefemoral process of the anal leg with 6-8 spines.

Distribution: North Columbia, Venezuella, Trinidad, Isla Margarita, Curacao Aruba and India (Maharashtra).

\section{REFERENCES}

Attems, C. (1930). Die Scolopendromorpha. Das Tierr 54(2): 1-302. Khanna, V. (1998). Records of the Giant Centipede Scolopendra gigantea Linnaeus from India - a case of mistaken identity. Zoos' Print 13(11): 38 .

Khanna, V. (2001). A checklist of the Indian species of the scolopendrid centipedes (Chilopoda: Scolopendromorpha). Annals of Forestry 9(2): 199-219.

Shelley, R.M. and S.B. Kiser (2000). Neotype designation and a diagnostic account for the centipedes, Scolopendra gigantea L. 1758, with an account of Scolopendra galapogoensis Bollman 1889 (Chilopoda: Scolopendrtomorpha: Scolopendridae). Tropical Zoology 13: 159-170. Yadav, B.E. (1997). First record of the Giant Centipede Scolopendra gigantea Linnaeus (Chilopoda: Scolopendridae) from India. Zoos' Print 12(5): 8 .

\section{ACKNOWLEDGEMENTS}

The authors are thankful to the Director, Zoological Survey of India, Kolkata and the Officer(s)-in-Charge of the Regional Stations of ZSI, for their support and encouragement.

International Conference on Biodiversity of Insects: Challenges Issues in Management and Conservation (BIMC)

30th January - 3rd February 2006

Dept. of Zoology, Bharathiar University, Coimbatore Tamil Nadu

\section{Conference themes}

- Insect Conservation and Taxonomy

- Biodiversity and Molecular Systematics of Insects

- Biodiversity and Management of Agricultural Insects

- Biodiversity, Management and Conservation of Forestry Insects

- Biodiversity and Management of Medical and Veterinary Insects

- Biodiversity and Biotechnological Advancement in Insects

For registration details and other information contact: Dr. K. MURUGAN

Reader/Organizing Secretary, BIMC,'06, Department of Zoology, Bharathiar University, Coimbatore 641046, India.

Phone (Off): +91-422-2422222 Ext: 481, 482, 483 \& 484

Tele Fax (Home): 2425015; Fax: 2422387, 2425706

E.mail:kmvvk@yahoo.com;kmvvk@rediffmail.com 